\title{
BOKO HARAM INSURGENCY AND VIOLENCE AGAINST WOMEN IN NORTH EASTERN NIGERIA
}

\author{
Mohammed Umar Bashir ${ }^{1}$ \\ Faculty of Social Sciences, University of Maiduguri. Nigeria. \\ (Email: tafidabashir@gmail.com) \\ Aisa Isa Geidam² \\ Faculty Social Sciences, University of Maiduguri, Maiduguri. \\ (Email: aisageidam@gmail.com) \\ Idris Mu' $\mathbf{a z u}^{3}$ \\ Faculty of Social Science, University of Maiduguri. Nigeria. \\ (Email: idrismuazu72@gmail.com)
}

Received date: $28-10-2019$

Revised date: 10-11-2019

Accepted date: 15-12-2019

Published date: 15-12-2019

To cite this document: Bashir, M. U., Geidam, A. I., Mu'azu, I. (2019). Boko Haram Insurgency and Violence Against Women in North Eastern Nigeria. International Journal of Modern Trends in Social Sciences, 2(10), 57-66.

DOI: $10.35631 /$ IJMTSS.210006

\begin{abstract}
Violence against women generally has attracted the attention of many scholars globally. This study examines the violence against women perpetrated by the Boko Haram insurgency in the affected area of North Eastern Nigeria, where the Boko Haram insurgency is more predominant. For the purpose of this research convenient sampling was used to explore the experiences of women. A qualitative method of data collection was used. Both secondary and primary data was obtained through face to face individual interview where the original information was gathered from 18 victims of Boko Haram violence in Maiduguri, Borno state capital. The research discovered that the violence experienced by women in the affected areas is both physical and psychological. However, the physical violation has been more pronounced, as women are used for suicide bombings and are as well sexually abused. Many women went through sexual violence; the threat of being killed and later on serves as suicide bombers under Boko Haram insurgent's custody. While some are still suffering from psychological trauma particularly those who witnessed the killings of either their children, spouses or other relatives. Furthermore, these women are mostly into small scale businesses in their homes such as knitting of caps, small poultry farms, animals fattening and etc but they were forced to abandon everything and ran for their lives. The study recommends psychosocial support to the victims and the provision of economic empowerment so as to enable the women to restart their businesses to give them a sense of belonging since most of them are business-oriented. This will help in making them adjust to new positive and favourable lives.
\end{abstract}

Key Words: Boko Haram, Insurgency, Violence, And Women 


\section{Introduction}

The Islamic sect in Nigeria which is popularly known as "Boko Haram" but calls itself as "Ahl as- Sunnah wal Jama'a ala Minhaj as-Salaf" which means: People of the way of the Prophet Muhammad (peace be upon him) and the community (of Muslims), which is in line with the earliest generation of Muslims. This name has good meaning that is acceptable by all Muslims (Da'wah Coordination Council of Nigeria, 2009). But when Mohammad Yusuf became its leader the name was renamed to suit his ideology. As the name was modified as follows: "Jama'atul Ahlis Sunnah Lidda'awati wal Jihad" which is translated as: the people who are dedicated to the propagation of the teachings of the prophet (Sunnah) and "Jihad" which means Islamic war (Meehan \& Speier, 2011; Chothia, 2012). However, the name Boko Haram was coined from the combination of Hausa word "Boko" which means western education and Arabic word "Haram" which means forbidden or a sin by the public and media agencies this is because the sect preaches against western education (Adesoji, $2010 \&$ Pham, 2012). Though, insurgency is not a new phenomenon, but Boko Haram is considered as new in northern Nigeria, this is because Nigeria as a country has never experienced deadly terrorist group like the Boko Haram. The violence attacks by Boko Haram in 2009 were mainly directed towards security agencies such the police, Military, Prison, political leaders, government structures, Islamic scholars who preach against Boko Haram. But subsequently, the insurgents changed their mode of operations to bombing of public places which claimed the lives of many innocent people (Geidam, 2017). The government in reaction through the military was able to capture Mohammed Yusuf the then leader of the group and handed him over to the police, but later was shot dead in the police custody. This led to a later attack that claimed eight hundred (800) lives (Okpaga et al., 2012).

After the dead of the first group leader (Mohammed Yusuf), the sects reinforced themselves under a new leader, by named Abubakar Shekau who was then the Deputy Amir who continues to launch attacks on innocent people. During the reign of Shekau as the leader of the sect, women were used as suicide bombers by Boko Haram in North-eastern Nigeria to attack public places and gathering following the threats and indoctrination by the sect in accordance with their own ideological beliefs (Maiangwa \& Agbiboa, 2014). Since then so many cases of abductions and kidnapping of women by the sect were recorded in different places. These include the abduction of 250 school girls in Chibok local Government, the kidnapping of 91 women, the abduction of 61 women in Adamawa state, later it was followed by the kidnapping of 180 women and the abduction of 105 Dapchi school girls in Yobe state (Vanguard newspaper, $14^{\text {th }}$ April 2014; The New York Times 2014; Reuters, 2014; Human Rights Watch, 2014; Saharan Reporters $24^{\text {th }}$ Feb, 2018 \& Premiuim Times Feb 23, 2018). However, very few scholars if any that have attempted to investigate the level of violence experienced by women in the insurgency affected area in the North Eastern States of Nigeria. This is because most of the scholars based their researches on socio economic effects of Boko Haram on Women, effect of the insurgency on the country at large, and number of victims involved as a result of the attacks. Awojobi, 2014; Ohiwerei, 2014; Zenn \& Pearson, 2014; Osita \& Chikere, 2015; Geidam, (2017). This has amounted to neglecting the aspect of violence on women perpetrated by the Boko Haram insurgents in the affected areas. Furthermore, most scholars depend on news as the sources of their information while this paper is based on empirical evidence. In view of the above, this paper intends to investigate the level of violence against women perpetrated by the Boko Haram insurgents in the North Eastern Nigeria. 


\section{Literature Review}

\section{Conceptual Definition of Woman}

Many scholars define women in relation to sex and gender. Thus, Stoller, (1968), observed that people can be categorized physiologically into male or female using the differences that enable women to bear and suckle children, these differences are referred to as sex. If male and female are to be used as sex, then corresponding term for identifying gender is masculine and feminine in order to be independent of biological or sexual attributes. Although, in Nigerian context and in this research paper woman is referred to as adult female who has attained the stage of adulthood.

\section{Concepts of Violence}

Violence is being studied across disciplines, each focusing on a specific system or unit of analysis: individual, group, institution/organization, nation states and politico-economic structures, and the international system (Joxe,2006). Thus, violence is divided into many different types. However, Newman (1979) stated that, violence may be the outcome of extreme emotional states such as rage, anger, or hate that may be directed towards people; these emotions may also be directed towards object or animal. While, World Health Organisation(WHO) \& Agagu, define violence as the intentional use of physical force on one another or against group or community, that will likely result to physical injury or death (Agagu, 2003 \& World Health Organization, 2008). Though, definitions above have explained what violence is in general, but this paper is interested in violence against women as a result of the insurgency in North Eastern Nigeria. As such the paper looked at violence against women specifically perpetrated by the Boko Haram insurgents so as to enable the reader to understand the subject matter of the paper. However, it may not be out of place if the paper looks at violence against women in general before narrowing to violence by the insurgents.

The United Nations Declaration on the Elimination of Violence against Women provides the following definition:

The term violence against women means any act of gender-based violence that results in, or is likely to result in, physical, sexual or psychological harm or suffering to women, including threats of such acts, coercion or arbitrary deprivation of liberty, whether occurring in public or private life. Violence can also be physical or psychological, Physical violence can include slaps, shoves, hits, punches, pushes, being thrown down stairs or across the room, kicking, twisting of arms, choking, and being burnt or stabbed. Psychological and emotional abuse can include a range of controlling behaviours such as control of finances, isolation from family and friends, continual humiliation, threats against children or being threatened with injury or death, United Nations Declaration on the Elimination of Violence against Women (UN, 2011).

Nonetheless, the violence experienced by the women in the Boko Haram affected areas is both physical, psychological but more of physical as women are used as suicide bombers and are as well sexually abused. Sexual assault or sexual violence can include rape, sexual assault with implements, being forced to watch or engage in pornography, enforced prostitution, and being made to have sex with friends of the perpetrator (WHO, 2017). 
Research has demonstrated that violence against women often involves a continuum of violence from psychological, economic and emotional abuse through to physical and sexual violence.

Bloom, (2007) stated that women are raped or abuse by insurgent as a recruitment tactics as this stigmatizes the women and making them easier to be exploit. Many women went through sexual violence, threat of being killed and later on serve as suicide bombers under the Boko Haram insurgents' custody (Bloom,2007)., Violent extremists are seen as being most likely to victimize women because of their often conservative or reactionary gender agendas. Personal trauma, most notably as a result of rape is one of the fundamental outcomes of violence against women by the extremist group.

\section{Insurgency}

The British Army Field Manual (AFM) referred to insurgency as an organized use of subversion and violence to seize, nullify or challenge political control of a region to gain political control over a geographic area including its resources.

Insurgency can also be seen as expanded political-military struggle directed towards subverting or displacing the legitimacy of a constituted government or occupying power and partially controlling the resources of a territory through the use of unlawful military forces (Guide to the Analysis of Insurgency 2002). In other words, is a political attempt to overthrow the legitimate authority by the oppositions for their selfish reasons.

\section{Empirical Cases of Violence Attacks on Women by The Boko Haram Insurgents}

Women have suffered various forms of attacks ranging from suicide bombing, mass killings, rape, kidnapping by the Boko Haram insurgents to mention but a few (Muinat, 2015:3). Boko Haram members have for some years harassed and abused both Christian and Muslim women. The year 2013 marked an important change in Boko Haram tactics, where the group carried out a series of kidnapping in which one of the main characteristics was the use of women. In May 2013 Boko Haram abducted 12 Women and Children during an attack in Bama (Zenn \& Pearson, 2014). Similarly, Boko Haram terrorist attacked the Air force Base and other places in Maiduguri, where the attack was reported to have started from 3am to 8am; several people of both sexes were killed this is because the terrorist was many in number who planted explosives in their targeted areas in the metropolitan area (Ndahi, 2013).

In another report by Vanguard newspaper, on $14^{\text {th }}$ April 2014, not less than 250 school girls were reported to have been abducted by the insurgents in Chibok Local Government of Borno State. This abduction has been the first largest incident that attracted international campaign and call on the Government of Nigeria to rescue the abducted girls. Also, in another report by international Newspaper, it was reported that other women numbering 91 were kidnapped by Boko Haram members in Borno State (The New York Times June $4^{\text {th }}$ 2014). Furthermore, Sahara Reporters reported that more than 60 women were abducted by Boko Haram insurgents in Adamawa State, North eastern Nigeria. Similarly, 174-185 villagers (women) were kidnapped by Boko Haram insurgents (Reuters report, $18^{\text {th }}$ of December 2014). In a related development, a female suicide bomber believed to be around 10 years carried out suicide bombing and killed 19 others. She carried out the bombing possibly against her will at a public place in Borno state. Furthermore, Reuters, (2014) reported that on the $18^{\text {th }}$ of December 2014, Boko Haram insurgents kidnapped over 180 women in the North East. Human Rights Watch, (2014) in its reports estimated that Boko Haram Sect has abducted more than 500 women and young girls from 2009 to 2014 from several towns and villages in the North Eastern Nigeria. However, in 
related report by the CNN, in Oct. $24^{\text {th }} 2014$, Boko Haram gunmen invaded the town of Mafa in Borno State and Kidnapped 30 boys and girls (Aminu, 2014). In 2018 the second largest case of school girl's abduction was recorded from Dapchi in Yobe state where 105 school girls were abducted by Boko Haram from Government Girls Science and Technical Collage Dapchi (Saharan Reporters 24 ${ }^{\text {th }}$ Feb, 2018 \& Premium Times Feb 23, 2018). The use of violence on women by the insurgent could not even spare underage girls as there was a report where two female suicide bombers around the ages of thirteen killed themselves and three others in a market place in Yobe State (Geidam, 2017). Since then Boko Haram had furthered their attacks in urban areas by the use of female suicide bombers (Faruok, 2015). In Gombe state a neighbouring state of Borno state on 8 January 2014, a woman came to a military barrack in on a motor bike and detonated an explosive killing herself and a police man (Farouk, 2014). Boko Haram have so many times abducted women for negotiation with government either for the release of their arrested members or families recently Boko Haram released a video in September 2018 threatening to kill two health workers of the International Committee of the Red Cross (ICRC), after executing the first woman by named; Saifura Khursa in September 2018 (Premium times, 16 Oct. 2018).

These use of violence on women and young girls by the Boko Haram insurgents, has let women to become vulnerable to sex abuses, premature death through suicide bombings which has persisted for some years in the North Eastern states of Nigeria particularly in Borno state which was known to be the headquarters of the sect before they fled to the Sambisa forest. As part of the violence against women the International Committee for the Red Cross (ICRC) has confirmed the execution of its worker, Hauwa Liman who is 24 years of age by Boko Haram terrorists. Hauwa who was said to have been abducted in an attack in the North-Eastern town of Rann on $1^{\text {st }}$ of March 2018, together with Saifura Hussaini Ahmed Khorsa and Alice Loksha of which Saifura was killed earlier on 16 September 2018. This has increased the numbers of the staff of (ICRC) that were killed by the insurgents to two (Othman A. \& Abdulateef, S. 2018).

\section{Methodology}

This study adopted the qualitative method of data collection through the use of face to face indepth interview with the women who have the experiences of violence in the insurgency affected areas in the North Eastern Nigeria. This research used both secondary and primary data. The secondary data were obtained through journals, books and the internet.

The sampling technique used for the study was convenience sampling where the women participated voluntarily as only those who have agreed to participate and are available for the exercise were interviewed in the internally displaced camp in Maiduguri, based on their convenience and having experience of violence. Thus 20 women who are victims of insurgency were sampled for interview but along the process two could not conclude the process due to emotional instability as tears could not allow them to continue with the interview as such only 18 were interviewed for the purpose of this study. 


\title{
Findings
}

\section{Sexual Abuses Experienced by Women During Insurgency}

Sexual abuse is one of the tactics adopted by Boko Haram in the past few years during their attacks in various parts of the North-Eastern States of Nigeria. Women of Borno State also experienced the same problem during the insurgency. One of the participants lamented that:

\begin{abstract}
A Boko Haram member entered my neighbour's house and said he must rape her, the woman pleaded with him, but he insisted, she further told him what he is demanding for is against Islam. The insurgent replied her that he knows but he must rape her. He gave the woman two options: either she agrees, or he kills her. The woman stated that she preferred to be killed. When he (Boko Haram) noticed that she was not ready to comply he insisted and raped her (Respondent 3).
\end{abstract}

Furthermore, another respondent reported that:

A member of Boko Haram insisted on raping one woman while the woman was on her menstruation period, but he insisted that he must rape her even in that situation. As he was trying to pull off her cloth, luckily for the woman another elderly woman screamed when she saw him in that process and that was how the woman escaped, and the insurgent ran away for fear of being arrested (respondent, 15).

During the interaction with the respondents, they lamented that sexual abuse was one of their worst experiences, especially when women became captives of Boko Haram. The insurgents kidnap and forcefully abduct and convert women as their 'wives' regardless of their marital status. This unpleasant development led to emotional instability in the lives of the women. Also, the experience of rape by Boko Haram has led to the death of women, the phenomenon had produced so many children for the terrorists and many unwanted pregnancies as stated by the respondents. One of the respondents explains that; 'Boko Haram' raped women, in fact a lot of women got pregnant as a result.' Furthermore, another respondent also stated that:

My daughter who was a student in Maiduguri the state capital was kidnapped by 'Boko Haram' members together with two daughters of my neighbours. Furthermore, my second daughter was raped and as a result the she died.....crying...... I don't really care about my lost properties my grievances are the ruining of the lives of my two daughters (Respondents and victim 12).

This finding is consistent with the findings of Osita \& Chikere, (2015) which reported that women suffered as a result of Boko Haram insurgency. Women were sexually abused and also held hostage on several occasions by the terrorists. Furthermore, is in line with the findings, of Liebling et al., (2013), women in Pula camp were sexually abused by terrorist which led to great effect on them not only that but also affected their physical and emotional conditions. In related findings by Chi et al., (2015) who opined that women experienced sexual abuses in Burundi and Uganda which resulted into unwarranted prostitution and transmission of HIV and other sexually transmitted diseases. Also, according to United Nations Fund for Population Activities (UNFPA) women and girls have always fallen victims of sexual abuse during war or conflict as 
most terrorists used it as a tactics which leads to different health problems among women and the adolescent girls especially life time trauma.

\section{Women Experience of Violence during Boko Haram Insurgency}

These are the responses of the women interviewed where they shared their experiences on various types of violent attacks they suffered from the insurgents. The violence experienced by women in the Book Haram affected area can never be forgotten by these women.

In a response by a victim of Boko Haram who is respondent to this research has this to say:

Boko Haram slaughter and kidnap people, they have also kidnapped and abducted our daughters, and they killed our youth during the insurgency we have buried the death bodies of many of our relations before we escaped. Because they are after men as such the men were forced to flee and abandoned the women as such there were no men, thus we were left with no option other to bury the dead bodies for the fear of outbreak of diseases. I was diagnosed and told that my lungs and liver are swollen (Participant 10).

Many respondents have the same views with this respondent who stated that:

Boko Haram attacked our village and began to shoot guns sporadically. Before we thought it was the military men that were shooting but later on it was discovered that it was Boko Haram insurgents. As such we took on our heels and started running for our lives with our children. But unfortunately, they killed 16 young men right behind our residence this made us become confused and more frightened. After that they started searching for youth from house to house. Wherever these youths were hiding themselves they will bring them out and kill them regardless of their numbers (Respondent1, and victim of violence).

Furthermore, some of the respondents said;

Boko Haram had attacked Bama town the headquarters of Bama local of Borno state, where they killed men, women, young and old. While others died in the process of running for their lives. Sometimes they killed and threw the dead bodies either in the well or even leave it on the street. Sometimes they take over a particular community for days. There was a time when they attacked Bama for days. As a result, our husbands have to run for their lives because that time they were after men throughout that period we were indoors without any food. While many dead bodies were left everywhere on the streets, and most of the dead bodies were men. We later decided to start burying the dead bodies until it was beyond our ability we gave up. This is because there were thousands of dead bodies all over the streets. After that we formed some groups and left the village (Respondent and Victim, 6).

However, this respondent further explains that:

The Boko Haram members in Gwoza Local Government were going from house to house to pick ladies and many of such ladies or women were kidnapped. Others who suffered from the Boko Haram are those women who gossiped against the 
insurgents were beaten to the state of unconsciousness. I was an eye witness to this. The whole town was deserted due to the destruction they caused, such as burning of both public and private buildings (Respondent and Victim 8).

The above results indicate that women have suffered a lot of violence in the North East of Nigeria as a result of Boko Haram insurgency. Despite the assistance by local and international Non-Governmental organisations, the state and federal agencies, such assistance is not enough. In addition, beyond material assistance, the victims of the insurgency particularly women need urgent psycho-social support to address the serious trauma they are going through.

\section{Discussion}

Violence against women as a results of terrorist and insurgents activities has been increasing globally and Nigeria in particular, this research has shown that Boko Haram insurgency violence does not only affect men as it was stated earlier by Geidam, where she opined that, violence attacks by Boko Haram in 2009 were mainly directed towards security agencies such as the police, Military, Prison officials, political leaders, government structures and Islamic scholars who preach against Boko Haram (Geidam, 2017). But subsequently, the insurgents changed their mode of operations to bombing of public places using women as suicide bombers which claimed the lives of many innocent people. Furthermore, the research discovered that women have suffered sexual violence as it was also reported by Liebling et al., (2013), where they stated that women in Pula camp were sexually abused by terrorist this violence have also affected their physical and emotional conditions. More so, in the north eastern Nigeria, women were only abused in the camp but also picked from their houses against their wishes by Boko Haram as it was stated by one of the respondents "Boko Haram members in Gwoza Local Government were going from house to house to pick ladies and many of such ladies were sexually abused" (Respondent, 8 and victim). This shows how serious the situation it is in Nigeria as compared to that in Pula camp where women suffered sexual abuse. However, women were not only kidnapped, sexually abused but also lost their lives as it was reported by a mother of a victim where she stated that: "my second daughter was raped and as a result of the rape she died" (Respondent, 12). Furthermore, many women abducted by the insurgents these women were not only abducted and rape under the custody of the insurgents but some of them were killed among those killed were Hauwa Liman who is 24 years of age and Saifura whom were both health workers working under International Committee Red Cross (Othman A. \& Abdulateef, S. 2018). While, some young girls are being forced to commit suicide without their wish as some were sent with explosives to detonate in public places as a result many young girls lost their lives. A female suicide bomber believed to being around 10 years carried out suicide bombing and killed 19 others (Reuters report, $18^{\text {th }}$ of December 2014). These have shown the levels of violence against women perpetrated by terrorist groups such as Boko Haram in other parts of the world and North Eastern Nigeria in particular are increasing which something has to be done in order to save the lives of women and children in war and conflict zones live Nigeria.

\section{Conclusion}

This study concludes that women in the insurgency affected areas of the North East have experienced so many types of violence as a result of the insurgency.

The research established that the violence experienced by women in the affected areas is both physical and psychological. However, the physical violation has been more pronounced, as women were used for suicide bombings and are as well sexually abused. Many women went 
through sexual violence; threat of being killed and later on they were forced to serves as suicide bombers by the Boko Haram insurgents.

Most notable among the physical violence are: sexual harassments such as rape, abductions, beatings where a woman refused to comply for their demands and at the end murdered or end up being raped. These women were used as suicide bombers through indoctrinations of young girls within the age range of 10 to 15 years. While some of the women are still suffering from psychological trauma particularly those that have witnessed the killings of either of their children, relations or husbands.

\section{Recommendation}

The study recommends immediate psychosocial support to the victims to enable the women get out of their psychological trauma. The women also need both material and financial support. Material support in the form of sewing machines, blending machines etc. are required as most of the women are into some small businesses in their homes before the Boko Haram insurgency. This will enable them to start their business again and restore livelihoods in the region.

Government should look for a way of resettling them back to their home towns and find a lasting security measure that will guarantee the safety of lives and property so as to prevent similar future occurrences.

\section{References}

Adesoji, A. (2010). The Boko Haram Uprising and Islamic Revivalism in Nigeria/Die BokoHaram- Unruhen und die Wiederbelebung des Islam in Nigeria. Africa Spectrum, Vol. 45(2), pp. 95-108.

Agagu, O. (2003). Welcome address. In Bash A. Olasupola (Ed.), Electoral violence In Nigeria: Issues \& Perspectives (pp. 1-3). Lagos: Friedrich Ebert Stiftung.

Aminu, A (2014): Boko Haram kidnaps 30 in northeast Nigeria. www.cnn.com 2014/10/27/world/africa/boko-haram abduction retrieved on $26^{\text {th }}$ Feb 2015.

Awojobi, O. N. (2014). The socio-economic Implications of Boko Haram Insurgency in the North-East of Nigeria International Journal of Innovation and Scientific Research, vol. 11(1), pp. 144-150.

Bloom, M. (2007). Female suicide bombers: a global trend. Daedalus, vol. 136(1), pp. 94-102

Carter, B. (2013). Women and violent extremism GSDRC Helpdesk Research Report

Chothia, F. (2012). Who are Nigeria's Boko Haram Islamists? BBC News of, 11

Chi, P. C., Bulage, P., Urdal, H., \& Sundby, J. (2015). Perceptions of the effects of armed conflict on maternal and reproductive health services and outcomes in Burundi and Northern Uganda: a qualitative study. BMC international health and human rights, vol. 15(1), pp. 1

Da'wah Coordination Council of Nigeria (DCCN), (2009). The "Boko Haram” Tragedy: Frequent asked Questions. Ilmi Avenue Minn, Nigeria.

Farouk, C (2014): Boko Haram crises: Nigeria's female bombers strike. www.bbc.com/news/world-africa-28657085

Farouk, C (2015): Who is Nigeria's Boko Haram Islamist? www.bbc.com/news/world-africa13809501

Geidam, Aisa Isa, (2017). The experience of women on Boko Haram insurgency: a case study of Bama Local Government displacement camp of Borno State, Nigeria. MSc Thesis submitted to department sociology, University Malaysia Sarawak.

Human Right Watch (2014): Those terrible weeks in cam 
Liebling-Kalifani, H., Marshall, A., Ojiambo-Ochieng, R., \& Kakembo, N. M. (2013). Experiences of women war-torture survivors in Uganda: implications for health and human rights. Journal of International Women's Studies, vol. 8(4), pp. 1-17.

Maiangwa, B., \& Agbiboa, D. (2014). Why Boko Haram kidnaps women and young girls in north-eastern Nigeria conflict trends, vol. 3, pp. 51-56.

Meehan and Speier (2011), Boko Haram, threat to the Home land. Washington; U S house of National Bureau of Statistics (2009) Social statistics in Nigeria, Abuja the NBS Publication

Muinat, A., (2015). Socio economic and political impact of Boko Haram terrorism in Nigeria. Unpublished

Newman, G. (1979). Understanding violence. Understanding violence. New York: Lippincott.

Newman, P. (2013). The etymology of Hausa boko Réseau Méga-Tchad, 2

Ohiwerei, F. O. Effects of Boko Haram Insurgency/Terrorism in Business Education in Nigerian Universities unpublished

Okpaga A.Chijioke, U S \& Eme, O .I (2012) Activities of Boko Haram and insecurity question in Nigeria. Arabian journal of business and management review, vol. 1(9), pp. 77-98

Osita-Njoku, A., \& Chikere, P. (2015). Consequences of Boko Haram terrorism on women in Northern Nigeria. Applied Research Journal, Vol.1 pp. 101-107.

Othman Abubakar \& Abdullateef Salau, (2018). Insurgents Killed health worker abducted in Borno Daily Trust Newspaper, p.4 September

Premium times, (2018). How Boko Haram attack, Kidnap of Dapchi School girls occurred. https://wwwpremiumtimesng.com/...259646-boko-haram-attack-kidnap-dapchischool-girls...23feb 2018

Pham, J. P. (2012). Boko Haram's evolving threat. Africa security briefs, vol. 20, pp.1

Saharan Reporters, (2018). How Boko Haram attack kidnap of Dapchi school girls occurred Saharanreporters.com/2018/02/23/howboko-haram-attack-kidnap-of-dapchi-schoolgirls-occured

The New York Times June $4^{\text {th }}, 2014$

United Nation, (2011). National Plan to Reduce Violence against Women and their Children Australian Government 2010-2022.

Vanguard Newspaper June 12 2011Boko Haram: Joint Security task force created Developing: http://www.nigeriamasterweb.com

WHO, (2017) Facts and detail of violence against women? https://www.who.int/newsroom/fact/detail/violence-against-women

Zenn, J., \& Pearson, E. (2014) Women, Gender and the evolving tactics of Boko Haram Journal of terrorism research, vol. 5(1), pp. 46-57 